\title{
On Studying the Hierarchy of Interrelationships amongst the Essential Skills for Successful Implementation of Inclusion in $K$ Curriculum of Schools
}

\author{
Remica Aggarwal \\ Recventures Education Services \\ Private Limited \\ Delhi, India
}

\author{
Veena Aggarwal \\ Recventures Education Services \\ Private Limited \\ Delhi, India
}

\author{
Yogender Singh \\ Aryabhatt College \\ University of Delhi \\ Delhi, India
}

\begin{abstract}
UNESCO [1] appeals to its member states to anchor their educational agenda on the four pillars of learning - learning to know, learning to do, learning to be, and learning to live together. These pillars are hallmarks of a high quality inclusive culture, values, and principles. These hallmarks can be achieved mainly by carrying out the premises of inclusion in the curriculum. It is a kind of curriculum that is powerful in respecting the sanctity and integrity of human rights - by nurturing cultures, values, and principles of tolerance, which transcends cultural, religious, gender, physical, emotional, social, economic, and other difference. Present research work tries to explore the various strategies describing the $\mathrm{K}$ curriculum using inclusive education and further tries to explore the interrelationship amongst them .
\end{abstract}

\section{Keywords}

K-curriculum; Inclusion; ISM methodology

\section{INTRODUCTION}

Inclusive education as a curricular trend carries the belief that all learners should be educated alongside their peers regardless of physical, cognitive, socio-emotional, and economic, language, cultural, and other perceived differences. School children, as peers of children with special needs, are co-implementers of the inclusive agenda. Inclusion necessitates affirming values and cultures - one of the dimensions of inclusion [2-5]. Stakeholders, thus, should possess a principled definition of inclusion and work towards attaining it; therefore, there is a need to undergo re-assessment of conceptions and, more importantly, behavior [4].

Inclusive education is broad as it also calls for reform to eliminate social exclusion brought about by untoward responses to diversity [5-6]. Booth et al. [7] contend that inclusion will never be attainable as there will always be emerging exclusionary themes and pressures over time. Intentional integration of values and principles of inclusion in the curriculum, however, is compelling and consequential. It will subsequently create an inclusive community, promote humane relationships [8] and combat developing discriminatory themes. As a result, a principled community that works toward the society it envisions to create - one that pursues belongingness, connectedness, and collective sense[9]-- will emerge.

\subsection{Why there is a need?}

- Children with perceived differences in a highly diverse classroom are often the subject of ridicule, bullying, and a high rate of rejection [10] inflicted by their peers.
- To date, few attempts have been made to investigate the impact of integrating values and cultures of inclusion in the systems' curricula and instructions - as a concrete action that can be done in response to this call. Studies about inclusive education focused mainly on children with perceived differences; little is known about how other stakeholders - especially class members - can promote inclusion.

- "Children supporting children" in an inclusive classroom is an indicator of a high-quality inclusive education program [4] as it is potent in removing possible barriers and exclusion in school communities.

Hence, it is imperative to integrate concepts of inclusion in the curriculum during this stage of development to mend and improve the attitudes and behaviors of the children that will consequently lead to inclusive values and principles.

The paper is organised as follows. Section 2 describes the various skills for successful adoption of inclusive education in K Curriculum of Schools. Section 3 highlights the ISM methodology whereas section 4 presents the case example.

\section{LITERATURE REVIEW OF THE ESSENTIAL SKILLS FOR INCLUSIVE EDUCATION IN K CURRICULUM OF SCHOOLS}

Some of the essential skills are as follows:

\subsection{Cultures and values of respect to plurality [CVR]}

CVRs are at the core of inclusion. The practice of a culture that seeks to embrace differences and highlights diversity creates a community that is supportive of the holistic development of all learners [10-11].

\subsection{Social competence [SC]}

There is a need to ensure that an upward - leaning social competence is among the milestones during early childhood for a later success in life like academic and social areas [1220].

\subsection{Rich classroom experiences [RCE]}

As the early childhood stage is believed to be a sensitive period for social-emotional learning [13, 21, 22]. McCartney \& Phillips [16]; it is strategic to provide rich classroom experiences [RCE] to support the learners in the development of his/her social skills ([23]; [13]; [16] ; [10];[24]). 


\subsection{Creating and maintaining social relationships [CMSR]}

Steedly et al. [25] provided a framework and described social skills as competencies that support an individual in creating and maintaining social relationships $[26,10]$.

\subsection{Miscellaneous Communication skills [MCS]}

Skills like identifying social cues, collaborating, communicating, taking turns, respecting the rights of others, and being sensitive to one's needs and of the others are prosocial skills that individual should have to promote a sense of community- which emerge at an early stage of life $[12,27 ; 13]$; [28];[31]; [12], [30] ; [29]; [16]; [10] .

\subsection{Interpersonal and knowledge skills [IKS]}

Understanding other's needs, solving problems, cooperating and negotiating emotions, expressing emotion, reading social situation accurately, adjusting behavior to meet the demands of different social situation and in initiating and maintain friendship, cultural competence (i.e. acquiring knowledge of, respect for and the ability to interact effectively and comfortably with people of varying ethnic or racial backgrounds), and adopting social values (i.e. caring, equity, honesty, social justice, responsibility, a healthy lifestyle and flexibility) are among the standards of social competencies[13]; [29]; [16]; [10]; [32]; [31].

\subsection{Capability of controlling emotions [CCE]}

Young children should become skilled in expressing their actions and feelings with others and capable of controlling and adjusting their emotions and actions appropriately during social interactions [10].

\subsection{Cooperation from stakeholders [CFS]}

As inclusion is a social construct, implementing it necessitates the cooperation of all its stakeholders- even the learners[33].

\subsection{Deliberate planning and}

\section{implementation of pedagogies [DPIP]}

Social skills entail deliberate planning and implementation of pedagogies - such as integrating it in the prescribed curriculum. ([10];[5]).

\subsection{Extensive communication [EC]}

A child who is able to express self, positively interact with his/her peers [16]. Therefore, children should learn to communicate extensively. It is, therefore, essential to provide experiences and opportunities to young children with which they can express themselves through various media in a nonintimidating and non-discriminatory manner.

\subsection{Responsibility [Re]}

Responsibility is the ability to take actions according to the standards of justice, rights, and the welfare of others, and to act by such a decision. Additionally, it is also the ability of the child to carry a task [34].

\subsection{Other regarding skills [ORS]}

The "other-regarding skill -- the capacity of the child to show support, help and develop a friendship with other children takes time to be expanded and enhanced [35].

\section{INTERPRETIVE STRUCTURAL MODELLING METHODOLOGY [ISM]}

Interpretive Structural Modeling methodology a.k.a ISM [42] is a known technique to map the relationships amongst the relevant elements as per decision maker's problems in a hierarchical manner. It begins with a series of events starting from the identification of elements, it moves to establishing the contextual relationships between elements through pair wise examination and then further moving on towards developing the structural self-interaction (SSIM) matrix using VAXO [42] and then initial reachability matrix and final reachability matrix and rearranging the elements in topological order using the level partition matrices. Finally, a diagraph can be obtained.

\section{DEVELOPMENT OF ISM MODEL: CASE EXAMPLE}

Around 12 challenges described in the above section 2 are being further studied for the possible inter-relationships amongst them. These are : Cultures and values of respect to plurality [CVR]; Social competence [SC]; Rich classroom experiences [RCE]; Creating and maintaining social relationships [CMSR]; Miscellaneous Communication skills [MCS]; Interpersonal and knowledge skills [ IKS]; Capability of controlling emotions [CCE] ; Cooperation from stakeholders [CFS] ; Deliberate planning and implementation of pedagogies [DPIP] ; Extensive communication [EC]; Responsibility [ Re] ; Other regarding skills [ORS].

\subsection{Construction of Structural self- interaction Matrix (SSIM)}

This matrix gives the pair-wise relationship between two variables i.e. $i$ and $j$ based on VAXO. SSIM has been presented below in Fig 1.

\subsection{Construction of Initial Reachability Matrix and final reachability matrix}

The SSIM has been converted in to a binary matrix called the Initial Reachability Matrix shown in fig. 2 by substituting V, $\mathrm{A}, \mathrm{X}, \mathrm{O}$ by 1 or 0 as per the case. After incorporating the transitivity, the final reachability matrix is shown below in the Fig 3.

Fig 1: SSIM matrix for pair wise relationship amongst barriers

\begin{tabular}{|l|l|l|l|l|l|l|l|l|l|l|l|l|l|l|}
\hline S. No. & Barriers & 1 & 2 & 3 & 4 & 5 & 6 & 7 & 8 & 9 & 10 & 11 & 12 \\
\hline & & CVR & SC & RCE & CMSR & MCS & IKS & CCE & CFS & DPIP & EC & Re & ORS \\
\hline 1 & CVR & & V & V & V & V & V & V & V & V & V & V & V \\
\hline 2 & SC & & & A & X & X & A & A & X & A & A & X & A \\
\hline 3 & RCE & & & & A & A & A & A & A & A & V & V & V \\
\hline 4 & CMSR & & & & & A & A & V & V & V & V & V & V \\
\hline
\end{tabular}




\begin{tabular}{|l|l|l|l|l|l|l|l|l|l|l|l|l|l|l|l|}
\hline 5 & MCS & & & & & & A & V & V & V & V & V & V \\
\hline 6 & IKS & & & & & & & V & V & V & V & V & V \\
\hline 7 & CCE & & & & & & & & V & V & V & V & V \\
\hline 8 & CFS & & & & & & & & & A & A & A & A \\
\hline 9 & DPIP & & & & & & & & & & V & V & V \\
\hline 10 & EC & & & & & & & & & & & X & X \\
\hline 11 & Re & & & & & & & & & & & & X \\
\hline 12 & ORS & & & & & & & & & & & & \\
\hline
\end{tabular}

Fig 2: Initial reachability matrix

\begin{tabular}{|c|c|c|c|c|c|c|c|c|c|c|c|c|c|}
\hline S. No. & Barriers & 1 & 2 & 3 & 4 & 5 & 6 & 7 & 8 & 9 & 10 & 11 & 12 \\
\hline & & CVR & $\mathrm{SC}$ & RCE & CMSR & MCS & IKS & CCE & CFS & DPIP & $\mathrm{EC}$ & $\mathrm{Re}$ & ORS \\
\hline 1 & CVR & 1 & 1 & 1 & 1 & 1 & 1 & 1 & 1 & 1 & 1 & 1 & 1 \\
\hline 3 & RCE & 0 & 1 & 1 & 0 & 0 & 0 & 0 & 0 & 0 & 0 & 1 & 1 \\
\hline 4 & CMSR & 0 & 1 & 1 & 1 & 0 & 0 & 1 & 1 & 1 & 1 & 1 & 1 \\
\hline 6 & IKS & 0 & 1 & 1 & 1 & 1 & 1 & 1 & 1 & 1 & 1 & 1 & 1 \\
\hline 7 & $\mathrm{CCE}$ & 0 & 1 & 1 & 0 & 0 & 0 & 1 & 1 & 1 & 1 & 1 & 1 \\
\hline 8 & CFS & 0 & 1 & 1 & 0 & 0 & 0 & 0 & 1 & 0 & 0 & 0 & 0 \\
\hline 9 & DPIP & 0 & 1 & 1 & 0 & 0 & 0 & 0 & 1 & 1 & 1 & 1 & 1 \\
\hline
\end{tabular}

Fig 3: Final reachability matrix

\begin{tabular}{|c|c|c|c|c|c|c|c|c|c|c|c|c|c|c|}
\hline S. No. & Barriers & 1 & 2 & 3 & 4 & 5 & 6 & 7 & 8 & 9 & 10 & 11 & 12 & \\
\hline & & CVR & $\mathrm{SC}$ & RCE & CMSR & MCS & IKS & CCE & CFS & DPIP & $\mathrm{EC}$ & $\operatorname{Re}$ & ORS & D.P \\
\hline 1 & CVR & 1 & 1 & 1 & 1 & 1 & 1 & 1 & 1 & 1 & 1 & 1 & 1 & 12 \\
\hline 2 & LSC & 0 & 1 & 1 & 0 & 0 & 0 & 0 & 1 & 0 & 0 & 0 & 0 & 10 \\
\hline 3 & RCE & 0 & 1 & 1 & 0 & 0 & 0 & 0 & 1 & 0 & 1 & 1 & 1 & 6 \\
\hline 4 & CMSR & 0 & 1 & 1 & 1 & 0 & 0 & 1 & 1 & 1 & 1 & 1 & 1 & 9 \\
\hline 5 & MCS & 0 & 1 & 1 & 1 & 1 & 0 & 1 & 1 & 1 & 1 & 1 & 1 & 10 \\
\hline 6 & IKS & 0 & 1 & 1 & 1 & 1 & 1 & 1 & 1 & 1 & 1 & 1 & 1 & 11 \\
\hline 7 & CCE & 0 & 1 & 1 & 0 & 0 & 0 & 1 & 1 & 1 & 1 & 1 & 1 & 8 \\
\hline 8 & CFS & 0 & 1 & 1 & 0 & 0 & 0 & 0 & 1 & 0 & 0 & 0 & 1 & 4 \\
\hline 9 & DPIP & 0 & 1 & 1 & 0 & 0 & 0 & 0 & 1 & 1 & 1 & 1 & 1 & 7 \\
\hline 10 & $\mathrm{EC}$ & 0 & 1 & 1 & 0 & 0 & 0 & 0 & 1 & 0 & 1 & 1 & 1 & 6 \\
\hline 11 & $\mathrm{Re}$ & 0 & 1 & 1 & 0 & 0 & 0 & 0 & 1 & 0 & 1 & 1 & 1 & 6 \\
\hline \multirow[t]{2}{*}{12} & ORS & 0 & 1 & 1 & 0 & 0 & 0 & 0 & 1 & 0 & 1 & 1 & 1 & 6 \\
\hline & De.P & 1 & 12 & 12 & 4 & 3 & 2 & 5 & 12 & 6 & 10 & 10 & 11 & \\
\hline
\end{tabular}

D.P : Driving power ; De.P : dependence power

\subsection{Level Partition}

From the final reachability matrix, reachability and final antecedent set for each factor are found. The elements for which the reachability and intersection sets are same are the top-level element in the ISM hierarchy. After the identification of top level element, it is separated out from the other elements and the process continues for next level of elements. Reachability set, antecedent set, intersection set along with different level for elements have been shown below in table 1 to table 11 .
Table 1: Iteration I

\begin{tabular}{|l|l|l|l|l|}
\hline $\begin{array}{l}\text { S.No } \\
\text {. }\end{array}$ & $\begin{array}{l}\text { Reachability } \\
\text { set }\end{array}$ & $\begin{array}{l}\text { Antecedent } \\
\text { set }\end{array}$ & $\begin{array}{l}\text { Intersectio } \\
\text { n set }\end{array}$ & $\begin{array}{l}\text { Lev } \\
\text { el }\end{array}$ \\
\hline $\mathbf{1 .}$ & $\mathbf{2 , 3 , 8}$ & $\begin{array}{l}\mathbf{1 , 2 , 3 , 4 , 5 , 6 , 7 , 8 ,} \\
\mathbf{9 , 1 0 , 1 1 , 1 2}\end{array}$ & $\mathbf{2 , 3 , 8}$ & \\
\cline { 1 - 3 }. & $2,3,8,12$ & $\begin{array}{l}1,3,4,5,6,7,8,9, \\
10,11,12\end{array}$ & $3,8,12$ & \\
& & $1,3,4,5,6,7,9,1$ & $3,10,11,12$ & \\
\hline 3. & $2,3,8,10,11,1$ & & \\
\hline
\end{tabular}




\begin{tabular}{|c|c|c|c|}
\hline & 2 & $0,11,12$ & \\
\hline 4. & $\begin{array}{l}2,3,8,9,10,11, \\
12\end{array}$ & $1,3,4,5,6,7,9$ & 3,9 \\
\hline 7. & $\begin{array}{l}2,3,7,8,9,10,1 \\
1,12\end{array}$ & $1,4,5,6,7$ & 7 \\
\hline 8. & $\begin{array}{l}2,3,4,7,8,9,10 \\
, 11,12\end{array}$ & $1,4,5,6$ & 4 \\
\hline 9. & $\begin{array}{l}2,3,4,5,6,7,8 \\
9,10,11,12\end{array}$ & $1,5,6$ & 5,6 \\
\hline 10. & $\begin{array}{l}1,2,3,4,5,6,7 \\
8,9,10,11,12\end{array}$ & 1 & 1 \\
\hline
\end{tabular}

Table 2: Iteration II

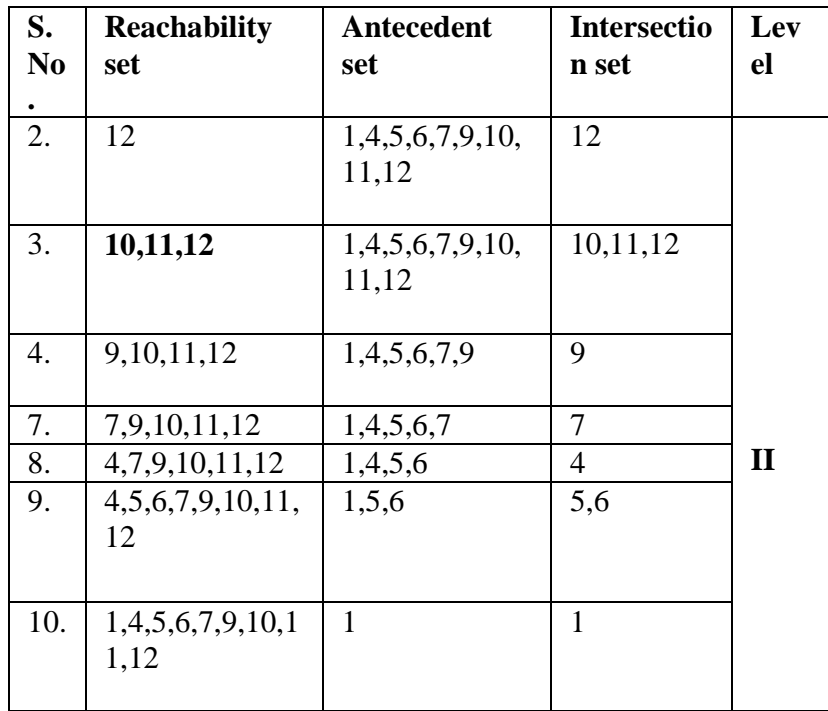

Table 3: Iteration III

\begin{tabular}{|l|l|l|l|l|}
\hline $\begin{array}{l}\text { S. } \\
\text { No } \\
\text {. }\end{array}$ & $\begin{array}{l}\text { Reachability } \\
\text { set }\end{array}$ & $\begin{array}{l}\text { Antecedent } \\
\text { set }\end{array}$ & $\begin{array}{l}\text { Intersectio } \\
\text { n set }\end{array}$ & $\begin{array}{l}\text { Lev } \\
\text { el }\end{array}$ \\
\hline 4. & $\mathbf{9}$ & $1,4,5,6,7,9$ & 9 & \\
\cline { 1 - 2 }. & 7,9 & $1,4,5,6,7$ & 7 & \multirow{2}{*}{ III } \\
\cline { 1 - 3 } 8. & $4,7,9$ & $1,4,5,6$ & 4 & \\
\hline 9. & $4,5,6,7,9$ & $1,5,6$ & 5,6 & 1 \\
\hline 10. & $1,4,5,6,7,9$ & 1 & 1 & \\
\hline
\end{tabular}

Table 4: Iteration IV

\begin{tabular}{|c|c|c|c|c|}
\hline $\begin{array}{l}\text { S.No } \\
\text {. }\end{array}$ & $\begin{array}{l}\text { Reachability } \\
\text { set }\end{array}$ & $\begin{array}{l}\text { Antecedent } \\
\text { set }\end{array}$ & $\begin{array}{l}\text { Intersectio } \\
\text { n set }\end{array}$ & $\begin{array}{l}\text { Lev } \\
\text { el }\end{array}$ \\
\hline 7. & 7 & $1,4,5,6,7$ & 7 & \multirow{4}{*}{ IV } \\
\hline 8. & 4,7 & $1,4,5,6$ & 4 & \\
\hline 9. & $4,5,6,7$ & $1,5,6$ & 5,6 & \\
\hline 10. & $1,4,5,6,7$ & 1 & 1 & \\
\hline
\end{tabular}

Table 5: Iteration V

\begin{tabular}{|l|l|l|l|l|}
\hline S.No. & Reachability set & $\begin{array}{l}\text { Anteceden } \\
\text { t set }\end{array}$ & $\begin{array}{l}\text { Intersectio } \\
\text { n set }\end{array}$ & $\begin{array}{l}\text { Lev } \\
\text { el }\end{array}$ \\
\hline 8. & $\mathbf{4}$ & $1,4,5,6$ & 4 & \\
\cline { 1 - 4 }. & $4,5,6$ & $1,5,6$ & 5,6 & \multirow{2}{*}{ V } \\
\cline { 1 - 3 } 10. & $1,4,5,6$ & 1 & 1 & \\
\hline
\end{tabular}

Table 6: Iteration VI

\begin{tabular}{|l|l|l|l|l|}
\hline $\begin{array}{l}\text { S.No } \\
.\end{array}$ & Reachability set & $\begin{array}{l}\text { Anteceden } \\
\text { t set }\end{array}$ & $\begin{array}{l}\text { Intersectio } \\
\text { n set }\end{array}$ & $\begin{array}{l}\text { Lev } \\
\text { el }\end{array}$ \\
\hline 9. & $\mathbf{5 , 6}$ & $1,5,6$ & 5,6 & \multirow{2}{*}{ VI } \\
\cline { 1 - 3 } & & 1 & 1 & \\
\hline
\end{tabular}

Table 7: Iteration VII

\begin{tabular}{|l|l|l|l|l|}
\hline $\begin{array}{l}\text { S.No } \\
\text {.Neachability }\end{array}$ & $\begin{array}{l}\text { Antecedent set } \\
\text { set }\end{array}$ & $\begin{array}{l}\text { Intersectio } \\
\text { n set }\end{array}$ & $\begin{array}{l}\text { Lev } \\
\text { el }\end{array}$ \\
\hline 10. & $\mathbf{1}$ & 1 & 1 & VII \\
\hline
\end{tabular}

\subsection{Classification of factors}

The critical success factors described earlier are classified in to four clusters viz. autonomous factor, dependent factors, linkage factors and independent / Driving factors are mentioned below.

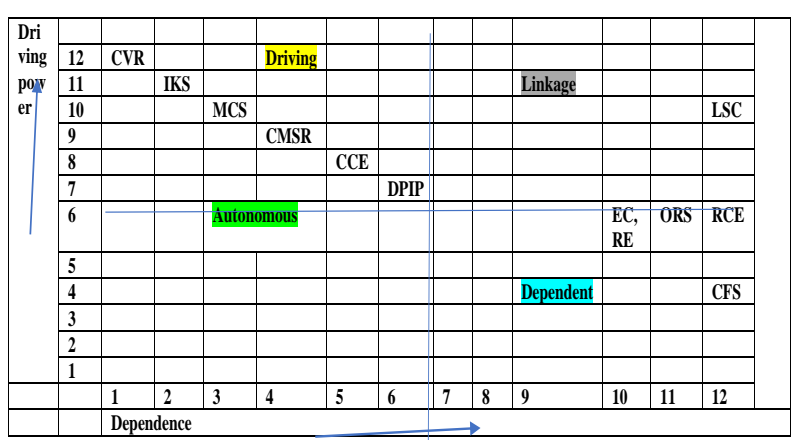

Fig. 4: Driving Power and Dependence Diagram

\section{CONCLUSIONS}

The present research presents the application of ISM methodology to establish or explore the interrelationships amongst the various skills necessary for the successful adoption of inclusive education in $K$ curriculum of schools.

\section{ACKNOWLEDGEMENTS}

Author Remica Aggarwal is thankful to Prof. S.P Singh of DMS, IIT Delhi for disseminating the knowledge about ISM methodology which has helped her in writing this piece of work.

\section{REFERENCES}

[1] UNESCO (2009a):The Salamanca Statement and Framework for Action on Special Needs Education. Retrieved from http://unesdoc.unesco.org UNESCO. (2009a).

[2] Farrell, P. 2002. Making special education inclusive: From research to practice. New York, NY: David Fulton Publishers 
[3] Howes, A., Davies, S. M. B., \& Fox, S. 2009. Improving the context for inclusion: Personalising teacher development through collaborative action research (1st ed.). London, UK: Routledge.

[4] UNESCO, 2009b : Guidelines for inclusion: ensuring access to education for all. http://unesdoc.unesco.org UNESCO. 2009b.

[5] UNESCO, 2016 : Policy guidelines on inclusion in education. Retrieved from http://unesdoc.unesco.org UNESCO. (2016).

[6] Training tools for curriculum development. Reaching out to all learners: A resource pack for supporting inclusive education.

http://www.unesco.org/education/pdf/15_62.pdf

UNESCO. (2017). A guide for ensuring inclusion and equality in education. http://unesdoc.unesco.org

[7] Ainscow, M. 2005. Developing inclusive education systems: What are the levers for change? Journal of Educational Change, 6(2) , 109-124. https://doi.org/10.1007/s10833-005-1298-4

[8] Mezquita - Hoyos, Y.N., Sanchez-Monroy, M.H., Morales-Martinez, G.E., Lopez-Ramirez, E.O., \& ReynaGonzales, M.R. 2018. Regular and special education Mexican teachers' attitudes toward school inclusion and disability. European Journal of Educational Research, 7(3), 421-430. https://doi.org/10.12973/eu-jer.7.3.4 21.

[9] Saldana, J. 2015. The coding manual for qualitative researchers (3rd ed.). Los Angeles, CA: SAGE Publication Ltd.

[10] S. Kennedy, A. 2018. Promoting the Social Competence of Each and Every Child in Inclusive Early Childhood Classrooms. Rijeka: IntechOpen. https://doi.org/10.5772/intechopen.80858

[11] Baglieri, S. and Shapiro, A. 2017. Disability studies and the inclusive classroom. Critical practices for embracing diversity in education (2nd ed.). New York, NY: Routledge.

[12] Darling-Churchill, K. E. and Lippman, L. 2016. Early childhood social and emotional development: Advancing the field of measurement. Journal of Applied Developmental Psychology, 45, 1-7. https://doi.org/10.1016/j.appdev.2016.02.002

[13] Han, S. and Kemple, K. 2006. Components of social competence and strategies of support: Considering what to teach and how. Early Childhood Education Journal, 34 (3), 241-246. https://doi.org/10.1007/s10643-006-0139-2

[14] Kemple, K. M. 2004. Let's be friends: Peer competence and social inclusion in early childhood programs. New York, NY: Teachers' College Press.

[15] Luecken, L. J., Roubinov, D. S. and Tanaka, R. 2013. Childhood family environment, social competence, and health across the lifespan. Journal of Social and Personal Relationships, 30(2), 171-178. https://doi.org/10.1177/0265407512454272

[16] McCartney, K. and Phillips, D. 2006. Blackwell handbook of early childhood development. Chicester, UK: Blackwell Publishing Ltd.

[17] Moore, J., Cooper, B. R., Domitrovich, C., Morgan, N., Jacobson, L. and Greenberg, M. 2015. The effects of an exposure to an enhaned preschool program on socialemotional functioning of at-risk children. Early Childhood Research Quarterly, 32, 127-138. https://doi.org/10.1016/j.ecresq.2015.03.004

[18] Garner, P. W. and Waajid, B. 2012. Emotion knowledge and self-regulation as predictors of preschoolers' cognitive ability, classroom behavior, and social competence. Journal of Psychoeducational Assessment, 30(4),

$330-343$.

https://doi.org/10.1177/0734282912449441

[19] Vahedi, S., Farrokhi, F. and Farajian, F. 2012. Social competence and behavior problems in preschool children. Iranian Journal of Psychiatry, 7(3), 126-134. Retrieved from https://www.ncbi.nlm.nih.gov/pubmed/23139694

[20] Agboola, A. and Tsai, K. 2012. Bring character education into classroom. European Journal of Educational Research, 1(2), 163- 170 https://doi.org/10.12973/eu-jer.1.2.163 .

[21] Raguindin, P. Z. J. 2020. Integrating concepts and expressions of inclusion in the $\mathrm{K}$ - Curriculum: The case of the Philippines. European Journal of Educational Research, 9(1), 305-317. https://doi.org/10.12973/eujer.9.1.305.

[22] Mccabe, P. and Altamura, M. 2011. Empirically valid strategies to improve social and emotional competence of preschool children. Psychology in the Schools, 48, 513540. https://doi.org/10.1002/pits.20570.

[23] Bierman, K. L and Erath, S. A. (2006). Promoting Social Competence in Early Childhood: Classroom Curricula and Social Skills Coaching Programs. In K. Cartney. \& D. Phillips (Eds.), Blackwell handbook of early childhood development (pp.595-615).

[24] Stagnitti, K., O'Connor, C. and Sheppard, L. 2012 Impact of the Learn to Play program on play, social competence and language for children aged 5-8 years who attend a specialist school. Australian Occupational Therapy Journal, 59(4), 302-311. https://doi.org/10.1111/j.1440-1630.2012.01018.x

[25] Steedly, K., Scwartz, A., Levin, M. and Luke, S. 2008 Social skills and academic achievement. Evidences for education. National Center for Children with Disabilities, 3(11), 1-7.

[26] Lynch, S. and Simpson, C. 2010. Social Skills: Laying the foundation for success. Dimensions of Early Childhood, 38(2), 3-12.

[27] Denham, S., Bassett, H and Zinsser, K. 2012. Early childhood teachers as socializers of young children's emotional competence. Early Childhood Education Journal, 40(3), 137-143. DepEd Memo No. 43, s. 2013.

[28] Jones, S. M. and Zaslow, M., Darling-Churchill, K. E., and Halle, T. G. 2016. Assessing early childhood social and emotional development: Key conceptual and measurement issues. Journal of Applied Developmental Psychology, 45, 42-48. https://doi.org/10.1016/j.appdev.2016.02.008

[29] Lynch, S. and Simpson, C. 2010. Social Skills: Laying the foundation for success. Dimensions of Early Childhood, 38(2), 3-12. 
[30] Rose-Krasnor, L. and Denham, S. 2009. Socialemotional competence in early childhood. In K.H. Rubin, W.M. Bukowski, \& B. Lairsen (Eds.) Social, emotional, and personality development in context. Handbook of peer interactions, relationships, and groups, 162-179. New York, NY: The Guilford Press.

[31] Yoder, N. 2014. Teaching the whole child: Instructional practices that support social-emotional learning in three teacher evaluation framework. Washington, DC: American Institutes for Research Center on Great Teachers and Leaders.

[32] Sendil, C. O. and Erden, F. T. 2012. Preschool Teachers' Strategies to Enhance Social Interaction Skills of Children during Playtime. Procedia - Social and Behavioral Sciences, 47, 918-923. https://doi.org/10.1016/j.sbspro.2012.06.757

[33] Odom, S., McConnell, S. and Brown, W. 2018. Social competence of young children: Conceptualization, assessment, and influences. In Brown, W.H., Odom, S.L., McConell, S.R. (Eds.), Social competence of young children: Risk, disability, and intervention (pp 3-30). Baltimore, MD: Brookes Philippine Constitution (1986).

[34] Bear, G. G., Manning, M. A. and Izard, C. E. 2003. Responsible behavior: The importance of social cognition and emotion. School Psychology Quarterly, 18(2), 140-157. https://doi.org/10.1521/scpq.18.2.140.21857.

[35] Malti, T., Gummerum, M., Keller, M., Chaparro, M. P. and Buchmann, M. 2012. Early sympathy and social acceptance predict the development of sharing in $\begin{array}{llll}\text { children. PloS One, 7(12), e52017. } & \end{array}$ https//doi.org/10.1371/journal.pone.0052017

[36] Enriquez, V. 1976. Philippine Psychology: Perspective and Direction. In Philippine psychology. Theory, methods, and use (pp.5-21). Quezon City, Philippines: University of the Philippines Press.

[37] Krippendorff, K. 1980. Content analysis : an introduction to its methodology. Beverly Hills, CA: SAGE Publications.

[38] Loden, M. 1995. Implementing diversity : Best practices for making diversity work in your organization. Toledo, OH: McGraw Hill, Education.

[39] Maxwell, J. 1996. Qualitative research design. An interactive approach. Thousand Oaks, CA: SAGE.

[40] Mendez, J., Fantuzzon, J. and Cicchetti, D. 2002. Profiles of social competence of low-income African-American preschool children. Child Development, 73(4), 10851100 .

[41] Mortari, L. and Ubbiali, M. 2017. The "MelArete" Project: Educating children to the ethics of virtue and care. European Journal of Educational Research, 6(3), 269-278. https://doi.org/ 10.12973/eu-jer.6.3.269.

[42] Warfield, J.N. 1974. Developing interconnection matrices in structural modeling. IEEE Transactions on Systems, Man, and Cybernetics, (1), 81-87. 